like whey out of cheese, and it may finally consolidatc as contemporaneous veins in the plutonic rock, as rlykes in the surrounding yolcanic rocks, or as rhyolitic lavas and tuffs at the surface. The ideas here thrown out appear to me to be capable of extension to other volcanic regions; but as the sequence in these regions is gencrally complicated by the coming in of basic rocks during the later phases of volcanic activity, it will not be advisable to enter more fully into tho subject on the present occasion.

The special characters which igneous rocks present, then, are to bc traced to the chemical and physical properties of the original magma and to the infuence of surrounding circumstances, Rocks, like minerals, are in a state of stable equilibrium when subjected to the conditions of their furmation. When subjected to ather conditions, whether physical or chemical, they usually undergo a change. The destruction and disintegration of igneous rocks by the various agents of denudation are familiar to every student of geology, and need not therefore be described on the present occasion.

I trust I have now said sufficient to show that the science of petrography is one of the greatest importance to the geologist of the present day. The remarks un ætiological petrography are, of course, only intended to illustrate the nature of this branch of the subject, and to show that conclusions of the greatest theoretical interest may be expected to follow from a careful consideration of the facts accuired by work in the other branch of the science.

\section{UNIVERSITY AND EDUCATIONAL} INTELLIGENCE

CAMBRIDGE. $-\Lambda$ Report recently issued gives particulars of the successful raising of the roof of the Mineralogical Museum to form a Morphological Laboratory on the new floor this created. The firm of builders who had furnished estimatcs ultimately declined the work, and the Department of Mechanism undertook it. Under the continual superintendence of Prof. Stuart and Mr. Lyon the work was so skilfully done that not a crack was occasioned in the ceiling of the Mincralogical Museum, and the deflection of the new timbers was so well calculated that no timber moved upwarls or downwards more than the eighth of an inch when the load came upon it. The cost was several hundred pounds less than the estimate. The roof raised was I ro leet long, and the weight fifty cons. A special vote of thanks is to be given to the: Department of Mechanism for tho care, skill, and cconomy with which the building operations wero conducted.

The Botanical I aboratory has cost a little over 800/.; the Morphological Laloratory has cost about 2500 .

In the Natural Science "Special" Examinations for the ordinary B. A. degree during the past year, the great majority of candidates chose Chemistry, and show'ed that they had bestowed considerable pains on laboralory work while yet they were only imperfectly acquainted with the rationale of the processes they cuployed. The candidates in Hitany had neglected systematic, and especially descriptive, bolany. In June the descriptions of ensy, woll-marked specimens of flowering-plants were so worthless, that it was difficult to find out, from some descriptions, to which of the specimens they were intended to apply.

Iu Mechanism and Applied Science book-work was satisfactorily done, but deductions and numerical applications were very imperfect. Drawing was well done, and the candidates also showed a practical acquaintance with the use of tools; but they did not sulficicntly connect their mathematical with their practical knowledge.

In the previous examination or little-go, Jevons's logic was set as an alternative subject to Paley with considerable success last year. Out of forly-four candidates only six failed. In arith. metic a knowledge of decimals and the use of common senso were strikingly wanting. The grastual elevation of standare in Euclid and Algebra of late yeurs appears to have produced beneficial results. The papers in Mechanics in the October examination (on entrance) wcre unsatisfactorily answered; the candidates had for the most part read treatises dealing with the subject incompletely and porularly.

The proposal to discontinue entirely the additional examination in Mathematics for Honours Candidales has been rejected by a large majority, it having been found impossible to provide any substitute which would command general assent.
Mr. M. C. Potter, Assistant Curator of the Herbarium, has been approved as a Teacher of Botany.

The Physiological class-rooms having again become seriously overcrowded, owing to the increase of the medical school, a scheme for building new class-rooms with a large lecturc-room is put forward by the Museums and Lecture Rooms Syndicate. The lecture-room is to be 45 feet by 40 , and 32 feet high, and is calculated to arconmodalc 247 students comfortably. A new class-room 80 fect long to accommodate roo students working at one lime is an important feature, and rooms will also be provided for Prof. Roy's temporary Pathological Laboratory. The estimate cost is gooo?.

\section{SCIENTIFIC SERIALS}

Tournal of Anatomy and Physiology, January, contains:Diseases of the reproductive organs in frogs, birls, and mammals, by J. B. Sutton (plate 8). - O Oviduct in an adult male skate, by J. D. Matthews (plate 9). - On the influences of some conditions on the metamorphosis of the blow-fly, by J. Davidson.-On the sources and the excrction of carbonic acid at the liver, by J. J. Charles.--On a method of maceration, by A. M. Taterson (plate Io).-Floating kidney, by D. Hepburn. - The movements of the ulna in rotation of the fore arm, by Thos. Dwight.-Disscction of a double monster, by A. Hill.--Relation of the alve. olar form of cleft palate to the incisor teeth and the intermaxillary bones. - The dumb-bell-shaped bone in the palate of Ornithorhynchus compared with the pre-nasal bone of the pig. - The infra-orbital suture; and an additional note on the oviducts of the Greenland shark, by W. Turner.-Anatomical notes.

Quarteriy Joumal of Microscopical Science, January, contains:-On the significance of Kupfer's vesicle, with remarks on other questions of vertebrate morphology (plate $\mathrm{x}$ ), by $\mathrm{J}$. T. Cunningham.-Blastopore, mesoderm, and metameric segmentation, by W. H. Caldwell (plate 2). - On the origin of the hypoblast in pelagic tcleostean ova, by G. Brook.-On the pre ence of eyes in the shells of certain Chitonida, and on the structure of these organs, by $\mathrm{H}$. N. Moseley (plates $4,5,6$ ). Archerina bolioni, nov. gen. et sp., chlorophyllogenous protozoon allied to Vampyrella, by E. Ray Lankester (plate 7). - On the apex of the root in Osmunda and Todea, by F. O. Bower (plates 7 and 8). - Correction of an crror as to the morphology of Weleritschia mirabilis, by F. O. Bower.-E. Van Beneden's researches on the maturation and fecundation of the ovum, by J. T. Cunningham (plate ro).-On the suprarenal bodies of vertebrata, by $W . \Gamma$. R. Weldon (plates it and 12 ). -On the life-history of certain British heterxcismal uredines, by $\mathrm{C}$. Plowright.-On the occurrence of clitin as a constituent of the cartilages of Limulus and Sepia, by W. D. Halliburton.

Fournal of the Royal Microscopical Society, February, contains:-On the apparatus for differentiating the sexes in bees and wasps. An anatumical investigation into the structure of the receptaculum seminis and adjacent parts, by $F$. R. Cheshire (plates I and 2)--On the occurrence of variations in the development of a Saccharomyces, hy C. F. Dowdeswell. - Notcs on the life-histories of some little-known Tyroglyphidæ, by A $D$. Michael (plate 3).- - The usual summary of current rescarches in zoology, botany, and microscopy.

THL American Naturalist, February, contains:-On the habits of some Arvicoline, by $\mathbb{E}, \mathbb{R}$. Quick and A. W. Butler. - On a parasitic copepol of the clam, by R. R. Wright. -On the rudimentary hind-limb of Megaptera, and on the fingermuscles in $M$. longimana and in other whales, by J. Struthers.The structure and development of the suspensory ligament of the fetlock in the horse, by J. D. Cunningham,-The Winooski or Wakefield marble of Vermont, by G. H. Perkins, $-\Lambda$ botanical study of the milc-gall found in the black walnut, by Lillie J. Martin... On the evolution of the Vertebrata, progressive and retrogressive, by E. D). Cope.

Rendiconti del Reale 1stitulo Lombardo, January 8.-Annual report on the work of the Institute in the varions branches of science and letters during the past year, by the Secretary.-Biographical notice of Baldassare Poli, by Prof. Carlo Cantoni.

January $\mathrm{I} 5 .-$ On the secular variations in the elements of terrestrial magnetism at Venice, by Ciro Chistoni. - On a rare case of congenital malformation of the bladder, by Dr. C. Fiorani. Extent of the diurnal oscillation of the magnet of declination at Milan in the year 1884 , by Prof. G. V. Schiaparelli $-O n$ the anatomy of the human brain, hy Ir. Casimiro Mondino.-On 
the appearance of Halley's comet in the year 1456, by Prof. G. Celoria.

Rivista Scientifico-Industriale, Jannary 15.-Influence of static electricity on lightning conductors, by Prof. Eugenio Canestrini. -On Trouvé's universal incandescent electric lamps (four illustrations), by the Editor.-On the various forms of Scleranthus marginatus, Gussone, by Dr. Leopoldo Nicotra.

Zeitschrift für wissenschaftliche Zoologie, December 1884 , contains :-Observations on the origin of the sexual cells in Obelia, by Dr. C. Hartlaub (plates II and 12).-Studies among the Amobæ, by Dr. A. Gruber (plates 13 and 14). - On the propagation and development of Rotifer vulgaris, by Dr. O. Zacharias (plate 16).-On the amoboid movements of the Spermatozoa of Polyphemus pediculus, by Dr. O. Zacharius.On the uropneustic system in Helicinæ, by Dr. H. v. Ihering (plate I7).-On the metamorphosis in Nephelis, by Dr. R. S. Bergh (plates 18 and 19).-On the intercellular spaces and bridges in epithelia, by P. Mitrophanow.

Morphologisches Fahrbuch, Band x. Heft 3, contains :-On the occurrence of spindle-shaped bodies in the yolk of young frog eggs, by Prof. O. Hertwig (plate 14).--Researches upon the Pori abdominales, by $\mathrm{H}$. Ayers (plate 15 ). - Contribution to a knowledge of the eye in gastropods, by $\mathrm{C}$. Hilger (plates 16 and 17), and a postscript by Dr. O. Buitschli.-Studies on the development of the medullary cord in bony fish, with observations on the first appendages of the germinal vesicle and the chorda dorsalis in Salmonidæ, by N. Goronowitsch (plates 18 to 21 ). - Dinosaurs and birds : a reply to Prof. W. Dames, by Dr. G. Baur.-On the carpi centrale, and on the morphology of the tarsus in the Mammalia, by Dr. G. Baur.-Remarks on the abdominal pores in fish, by Prof. C. Gegenbaur.

\section{SOCIETIES AND ACADEMIES LONDON}

Royal Society, January 13.- "On the Constant of Electromagnetic Rotation of Light in Bisulphide of Carbon." By Lord Rayleigh, F.R.S.

A complete account is here given of the experiments briefly referred to in the Preliminary Note, ${ }^{1}$ and of others on the same plan of more recent date. As regards the method, it may be sufficient to add to what was there said, that the electric currents were estimated by comparing the difference of potential generated by the current in traversing a known resistance with that of a standard Clark cell, the value of the cell being known by converse operations, in which the current was measured by a special electro-magnetic apparatus. ${ }^{2}$ Allowance being made for temperature, the determination of the currents by this method was abundantly accurate and very simple.

The results are grouped in three series, of which the first two were considered in the Preliminary Note. In both of them the same tube was used, the principal difference being that in the first the light traversed the tube three times, and in the second but once. In the third series another tube was employed, and some improvements in respect to thermal insulation were introduced. The readings were taken with a double-image prism in place of the ordinary analysing Nicol, a substitution by which it is believed some advantages were obtained.

From the fifteen sets of observations of Series I. we find as the rotation of sodium light in bisulphide of carbon at $18^{\circ}$ corresponding to a difference of potential equal to unity C.G.S. the value ${ }^{\circ} 04203$ minute. From the four observations of Series II. we get in like manner 04198 minute, and from the seven observations of Series III. 04202 minute. The last value is adopted as the most probable,

In an appendix some remarks are made upon polarimetry in gencral, especially in relation to the half-shade method. $\Lambda$ device proposed by $M$. Becquerel for augmenting the precision with which rotations can be determined with the aid of a halfwave plate is considered, and the conclusion is arrived at that no advantage can thus be obtained.

February 19.- "Note on a Preliminary Comparison between the Dates of Cyclonic Storms in Great Britain and those of Magnetic Disturbances at the Kew Observatory." By Balfour Stewart, F.R.S., and Wm. Lant Carpenter.

The authors had made this comparison, through the kindness

x Proc. Roy. Soc. vol. xxxvii. p. ${ }^{4} 6$.

2 "On the Electro-chemical Equivalent of Silver, and on the Absolute electromotive Force of Clark Cells." Proc. hoy. "Soc, vol, xxxvii. p. I42. of Mr. Whipple, in the case of about thirty storms, the dates of which were taken haphazard from those given by Mr. R. H. Scott in his paper on the cyclonic storms of the last ten years, in the Quarterly Fournal of the Meteorological Society for October, 1884. Out of these thirty cases, in twenty-three there war a distinct magnetic disturbance, for the most part preceding the storm by somewhat more than a day. The authors intend to pursue the subject, considering that there is a prim $\hat{a}$ facie case for investigation.

Geological Society, February 20.-Annual General Meeting.--Prof. T. G. Bonney, F.R.S., President, in the chair.The Council's Report announced the awards of the various medals and of the proceeds of the Donation Funds in the gift of the Society. - In handing the Wollaston Gold Medal to Dr. W. T. Blanford, F.R.S., for transmission to Mr. George Busk, F.R.S., F.G.S., the President addressed him as follows:--The Council of the Geological Society has awarded to Mr. George Busk the Wollaston Medal in recognition of the value of his researches in more than one branch of palæontology. Polyzoa, not only fossil, but also recent, he has made peculiarly his own, and his numerous separate papers, his British Museum Catalogue, and his memoir on the Polyzca of the Crag, have entitled him to the lasting gratitude of workers at this class of the Molluscoida. But, perhaps as a relief to the study of these minute invertebrates, he has occupied himself, not less successfully, with the larger vertebrata, so that to him we are indebted for much information on the fauna of Post-tertiary deposits, especially from the caves of Malta and of Brixham. Permit me, in handing you this medal for transmission to Mr. Busk, to express my pleasure at having such a duty to discharge, and my earnest hope, in which I am sure all present will share, that restored health may enable him to continue his work in the cause of our science. - The President then presented the balance of the proceeds of the Wollaston Donation Fund to Dr. Charles Gallaway, F.G.S., and addressed him as follows:-The Council of the Geological Society has awarded to you the balance of the proceeds of the Wollaston Donation Fund, in recognition of the value of your researches among the older British rocks. By your identification of Upper Cambrian rocks in Shropshire you have placed beyond question the antiquity of the Rhyolitic Group of the Wrekin, our knowledge of which and of yet older rocks in that district you have greatly augmented. Your contributions also to the geology of Anglesey and to unravelling the stratigraphy of the Scotch High. lands have been of great value, and we look forward to the results of further researches, in aid of which I have great pleasure in placing in your hands the amount of the award. That you receive it from a fellow-labourer will, I hope, make it not the lass welcome. The President then handed the Murchison Medal to Dr. Henry Woodward, F.R.S., for transmission to Dr. Ferdinand Römer, F.M.G.S., of Breslau, and addressed him as follows :- The Council has awarded to Dr. Ferdinand Römer the Murchison Medal and a sum of ten guineas from the Donation Fund. His life-long and unwearied labours in the service of our science have long since made his name familiar to his fellowworkers. When I state that the Royal Society Catalogue, published now more than eleven years since, records the titles of I22 separate memoirs written by him, when I mention his other important works, such as that on "The Chalk Formation of Texas," on "The Silurian Fauna of Tennessee," on "The Geology of Upper Silesia," and the "Lethæa Geognostica," I have said enough to prove that this memorial of an illustrious geologist could not well have been bestowed on a more illustrious recipient. In transmitting it to Dr. Römer, be so lind as to express our regret that the distance and the season of the ycar have deprived us of the pleasure of his presence in this occasion. In presenting the balance of the proceeds of the Murchison Geological Fund to Mr. Horace $\mathrm{B}$. Woodward, F.G.S., the President addressed him as follows :-The balance of the proceeds of the Murchison Donation Fund has be 11 awarded to you in recognition of the good service which yout have already rendered to geology, especially by your work among the later deposits of the eastern counties, and to aid you in further researches. But the excellent papers which you have written, in addition to the work done by you as a member of the Geological Survey, do not constitute your only claim to our recognition. You have made use of the opportunity of your official position to promote a love of science among those who live in our eastern counties, and we are indebted to you for that admirable volume, "The Geology of England and Walcs," which, though in onc sense a compilation, is such a one as only 